\title{
Induction of Labor using Misoprostol in a Tertiary Hospital in the Southeast of Brazil
}

\section{Indução de parto utilizando misoprostol em um hospital terciário no sudeste do Brasil}

\author{
Tácito Augusto Godoy Silva ${ }^{1}$ Luciano Eliziário Borges Júnior ${ }^{1}$ Luisa Almeida Tahan ${ }^{1}$ \\ Taynná Ferreira Arantes Costa ${ }^{1}$ Fernanda Oliveira Magalhães ${ }^{1} \quad$ Alberto Borges Peixoto $^{1}$ \\ Wellington de Paula Martins ${ }^{2}$ Edward Araujo Júnior ${ }^{3}$
}

${ }^{1}$ Mário Palmério Hospital Universitário, Universidade de Uberaba (UNIUBE), Uberaba, MG, Brazil

2 Department of Obstetrics and Gynecology, Faculdade de Medicina de Ribeirão Preto, Universidade de São Paulo (FMRP-USP), Ribeirão Preto, SP, Brazil

3 Department of Obstetrics, Escola Paulista de Medicina, Universidade

Federal de São Paulo (EPM-UNIFESP), São Paulo, SP, Brasil Address for correspondence Alberto Borges Peixoto, MD, Avenida da
Saudade, 550 apto. 602 Ed. Parque dos Buritis, 38061-000 - Uberaba -
MG, Brasil (e-mail: albertobpeixoto@gmail.com).

Rev Bras Ginecol Obstet 2017;39:523-528.

\begin{abstract}
Keywords

- labor induction

- misoprostol

- oxytocin

- cesarean sections
\end{abstract}

Resumo
Purpose To assess cases of labor induction with vaginal $25-\mu \mathrm{g}$ tablets of misoprostol and maternal outcomes in a tertiary hospital in southeastern Brazil.

Methods This was a retrospective cohort study of 412 pregnant women with indication for labor induction. Labor induction was performed with vaginal $25-\mu \mathrm{g}$ tablets of misoprostol in pregnant women with Bishop scores $<6$. Stepwise regression analysis was used to identify the factors present at the beginning of induction that could be used as predictors of successful labor induction.

Results A total of $69 \%$ of the pregnant women who underwent labor induction progressed to vaginal delivery, and $31 \%$ of the women progressed to cesarean section. One or two misoprostol tablets were used in 244 patients (59.2\%). Of the 412 patients, $197(47.8 \%)$ required oxytocin later on in the labor process, after induction with misoprostol. The stepwise regression analysis showed that only Bishop scores of 4 and 5 and previous vaginal delivery were independent factors with statistical significance in the prediction of successful vaginal labor induction ( $\beta=0.23, p<0.001$, for a Bishop score of 4 and 5 , and $\beta=0.22, p<0.001$, for previous vaginal delivery).

Conclusion Higher Bishop scores and previous vaginal delivery were the best predictors of successful labor induction with vaginal $25-\mu \mathrm{g}$ tablets of misoprostol.

Objetivo Avaliar os casos de indução do trabalho de parto com misoprostol $25 \mathrm{mcg}$ por via vaginal e seus desfechos maternos em um hospital terciário do Sudeste do Brasil. received

March 3, 2017

accepted

May 30, 2017

published online

July 12, 2017
DOI https://doi.org/

10.1055/s-0037-1604259.

ISSN 0100-7203.
Copyright $\odot 2017$ by Thieme Revinter

Publicações Ltda, Rio de Janeiro, Brazil
License terms

(ㄷ) (i) $\ominus$ (5) 


\author{
Palavras-chave \\ - indução de parto \\ - misoprostol \\ - ocitocina \\ - parto cesárea
}

\begin{abstract}
Métodos Realizou-se um estudo retrospectivo de coorte com 412 gestantes com indicações para indução de trabalho de parto. A indução do trabalho de parto foi realizada com misoprostol 25 mcg vaginal em gestantes com índice de Bishop $<6$. Realizou-se análise de regressão stepwise para identificar os fatores presentes ao início da indução que poderiam ser usados como prognosticadores do sucesso da indução do trabalho de parto.

Resultados A indução de trabalho de parto determinou 69\% de partos normais, sendo que $31 \%$ evoluíram para cesárea. Em relação ao número de comprimidos de misoprostol, 1 ou 2 comprimidos foram utilizados em 244 pacientes (59,2\%). Das 412 pacientes, $197(47,8 \%)$ necessitaram de ocitocina após a indução com misoprostol para dar continuidade ao trabalho de parto. $\mathrm{Na}$ análise de regressão stepwise, apenas a presença de índice de Bishop 4 e 5 e parto vaginal prévio foram fatores independentes com significância estatística na predição do sucesso da indução em obter parto vaginal $(\beta=0,23, p<0,001$, para índice de Bishop 4 e 5 , e $\beta=0,22, p<0,001$, para parto vaginal prévio).

Conclusão Maiores índices de Bishop e parto vaginal prévio são os maiores prognosticadores do sucesso de indução de trabalho de parto com misoprostol $25 \mathrm{mcg}$ vaginal.
\end{abstract}

\section{Introduction}

Labor induction is any procedure that stimulates uterine contraction before labor begins naturally. ${ }^{1,2}$ It is indicated when the maternal/fetal associated risks with the pregnancy are higher than the maternal/fetal associated risks of early delivery. $^{3}$ The most common causes of labor induction are prolonged gestation ( $>42$ weeks), preeclampsia, and premature rupture of membranes. ${ }^{3}$

For the induction of labor, it is necessary to administer labor inducers. The main mechanical methods are the following: artificial rupture of membranes (amniotomy), breast stimulation, cervical dilators (Hegar dilators and laminaria tents), and digital sweeping in the lower segment. ${ }^{4}$ Pharmacological methods include the use of oxytocin and synthetic prostaglandins. ${ }^{1,2}$

Misoprostol is a synthetic prostaglandin E1 (PGE1) analogue that acts as an inducer of the ripening process, thus favoring dilation and causing uterine contractions. ${ }^{5}$ It is indicated for labor induction in cases of unfavorable uterine cervix (Bishop score $<6$ ). ${ }^{6}$ Misoprostol can be administered via the vaginal, ${ }^{7}$ oral, ${ }^{8}$ and sublingual ${ }^{9}$ routes, with the vaginal route being the preferred one. However, misoprostol has contraindications, such as previous cesarean delivery, previous uterine surgery, placenta previa, asthma, coronary disease, and cephalopelvic disproportion. ${ }^{10}$ The risks associated with labor induction using misoprostol are uterine hyperstimulation with hypertonia, tachysystole, and uterine rupture. ${ }^{11}$

The objective of this study was to evaluate pregnant women submitted to induction of labor through vaginal $25-\mu \mathrm{g}$ tablets of misoprostol and the maternal outcomes in a tertiary hospital in the Southeast of Brazil.

\section{Methods}

A retrospective cohort study was conducted between November 2014 and August 2016 in a maternity in the Southeast of Brazil. The sample comprised pregnant women with indication for labor induction with vaginal misoprostol. The inclusion criteria were singleton pregnancy with live fetus, gestational age $>40$ weeks, and premature rupture of membranes $>34$ weeks in the absence of signs of maternal infection. The exclusion criteria were previous uterine scar, cephalopelvic disproportion, and abnormal presentations. The study was approved by the Research Ethics Committee (CAAE: 62832016.7.0000.5145), and informed consent was obtained from the participants.

Labor induction was performed with $25-\mu \mathrm{g}$ tablets of misoprostol in pregnant women with Bishop scores $<6$. The drug was inserted in the posterior vaginal fornix at a dosage of 1 tablet every 6 hours for a maximum period of 48 hours ( $200 \mu \mathrm{g}=8$ tablets). In the cases in which labor was initiated, oxytocin was administered by a continuous infusion pump at an initial rate of $12 \mathrm{~mL} / \mathrm{h}$ and increasing to $196 \mathrm{~mL} / \mathrm{h}$. In cases of absence of labor, induction was deemed unsuccessful after eight tablets were inserted in the vagina of a pregnant woman with an intact amniotic sac and without changes in the uterine cervix. In cases of premature rupture of membranes, induction was deemed unsuccessful after four tablets were inserted and no changes occurred in the uterine cervix.

The dependent variables of this study were mode of delivery (vaginal or cesarean section), amniotic sac condition (intact or ruptured), number of tablets used (one to eight tablets), and duration of labor (time in hours between the beginning of induction and delivery). The control variables were maternal age and parity. The women selected for the study were 
recruited through a search in the computerized medical record system (Soul MV, MV Informática Nordeste Ltda, Recipe, PE, Brazil) of one of our institutions using the term misoprostol $25 \mu \mathrm{g}$ as the search filter. Subsequently, an active search on the medical records obtained from the previous search to collect the relevant data on the procedure was conducted.

The data were entered into an Excel 2010 spreadsheet (Microsoft Corp., Redmond, WA, USA), and the statistical analyses were performed using the IBM SPSS statistics software, version 23.0 (IBM Corp., Armonk, NY, USA). We considered vaginal deliveries as successful inductions of labor, and the absence of uterine contractions/uterine cervix modifications or any intercurrence during the labor culminating with cesarean section was considered as unsuccessful induction of labor.

Initially, we compared the maternal variables of the pregnant women with those of the women who progressed to cesarean delivery using the unpaired Student $t$-test and Fisher exact test. Then, we performed a stepwise regression analysis to identify the factors present at the beginning of induction that could be used as predictors of successful induction. Subsequently, we compared the women that exhibited these characteristics with those who did not. In all of the analyses, the level of significance $(p)$ was set at $5 \%$.

\section{Results}

The study included 412 pregnant women with indication for labor induction. The majority of patients (51\%) were aged between 20 and 30 years. In 244 patients (59.2\%), 1 or 2 tablets of misoprostol were sufficient to achieve the expected effect, and 117 patients (28.4\%) required 3 or 4 tablets. Regarding the Bishop score before labor induction, 241 patients (58.5\%) had a score between 2 and 3, and 171 patients (41.5\%) had scores between 4 and 5 .
In our sample, 197 (47.8\%) patients required oxytocin after induction with misoprostol for labor progression, and 215 patients (52.2\%) did not need it. The induction of labor led to $69 \%$ of normal deliveries, and $31 \%$ of women progressed to cesarean delivery. The indications for cesarean section were the following: unsuccessful induction (10.9\%); fetal bradycardia (10.7\%); placental abruption (0.7\%); secondary arrest of dilation (7.8\%); and secondary arrest of descent $(1.7 \%)$. The distribution of women according to the time (in hours) elapsed between the beginning of induction and delivery was the following: $12 \%$ between 4 and 7 hours; $18 \%$ between 8 and 11 hours; $17 \%$ between 12 and 15 hours; $13 \%$ between 16 and 19 hours; $23 \%$ between 20 and 29 hours; and $16 \%>30$ hours of induction.

- Table 1 shows the maternal outcomes of the pregnant women submitted to induction of labor with misoprostol that progressed to vaginal delivery (successful induction) or cesarean delivery (unsuccessful induction). The variables previous deliveries, parity, Bishop score, number of misoprostol tablets, time of induction, use of oxytocin, and previous vaginal delivery were associated with successful labor induction.

The stepwise regression analysis showed that only Bishop scores of 4 and 5 (-Table 2 ) and previous vaginal delivery (-Table 3) were independent factors with statistical significance in the prediction of successful vaginal labor induction with misoprostol $(\beta=0.23, p<0.001$, for Bishop scores of 4 and 5 , and $\beta=0.22, p<0.001$, for previous vaginal delivery).

\section{Discussion}

Misoprostol is considered the standard method for obtaining cervical maturity and, currently, for inducing labor. It is believed that $25 \mu \mathrm{g}$ of this drug administered vaginally is the ideal dosage for pregnant women with viable fetuses. ${ }^{12,13}$

Table 1 Comparison between the maternal variables according to successful (vaginal birth) and unsuccessful (cesarean section) labor inductions with misoprostol

\begin{tabular}{|c|c|c|c|c|c|}
\hline & \multicolumn{2}{|c|}{$\begin{array}{l}\text { Successful vaginal birth } \\
(n=285)\end{array}$} & \multicolumn{2}{|c|}{$\begin{array}{l}\text { Cesarean section } \\
(n=127)\end{array}$} & \multirow[b]{2}{*}{$p$} \\
\hline & Mean & SD & Mean & SD & \\
\hline Age (years) & 24.7 & 6.2 & 24.2 & 6.0 & 0.45 \\
\hline Number of previous deliveries & 2.0 & 1.4 & 1.6 & 0.9 & 0.001 \\
\hline Parity & 0.9 & 1.2 & 0.3 & 0.8 & $<0.001$ \\
\hline Number of previous miscarriages & 0.1 & 0.4 & 0.2 & 0.5 & 0.06 \\
\hline Bishop score & 3.5 & 1.1 & 2.8 & 0.8 & $<0.001$ \\
\hline Number of misoprostol tablets & 2.3 & 1.5 & 3.6 & 2.4 & $<0.001$ \\
\hline \multirow[t]{2}{*}{ Time of induction (hours) } & 16.5 & 9.9 & 23.6 & 13.9 & $<0.001$ \\
\hline & $N / n$ & $\%$ & $\mathrm{~N} / \mathrm{n}$ & $\%$ & $p$ \\
\hline Ruptured amniotic sac & $103 / 285$ & $36 \%$ & $40 / 127$ & $31 \%$ & 0.37 \\
\hline Use of oxytocin & $151 / 285$ & $53 \%$ & $46 / 127$ & $36 \%$ & 0.002 \\
\hline Previous vaginal birth & $130 / 285$ & $46 \%$ & $23 / 127$ & $18 \%$ & $<0.001$ \\
\hline Successful vaginal birth & $144 / 285$ & $51 \%$ & $27 / 127$ & $21 \%$ & $<0.001$ \\
\hline
\end{tabular}

Abbreviation: SD, standard deviation. 
Table 2 Stepwise regression analysis to predict the success of labor induction with misoprostol according to Bishop score

\begin{tabular}{|c|c|c|c|c|c|}
\hline & \multicolumn{2}{|c|}{$\begin{array}{l}\text { Bishop score between } \\
4 \text { and } 5 \\
(n=171)\end{array}$} & \multicolumn{2}{|c|}{$\begin{array}{l}\text { Bishop score between } \\
2 \text { and } 3 \\
(n=241)\end{array}$} & \multirow[b]{2}{*}{$p^{*}$} \\
\hline & Mean & SD & Mean & SD & \\
\hline Age (years) & 25.0 & 6.1 & 24.3 & 6.1 & 0.23 \\
\hline Number of previous births & 2.1 & 1.4 & 1.7 & 1.1 & 0.001 \\
\hline Parity & 0.9 & 1.3 & 0.5 & 1.0 & 0.001 \\
\hline Number of previous miscarriages & 0.2 & 0.4 & 0.2 & 0.5 & 0.96 \\
\hline Bishop score & 4.4 & 0.5 & 2.5 & 0.5 & $<0.001$ \\
\hline Number of misoprostol tablets & 1.8 & 1.2 & 3.3 & 2.1 & $<0.001$ \\
\hline \multirow[t]{2}{*}{ Time of induction (hours) } & 13.2 & 8.1 & 22.6 & 12.3 & $<0.001$ \\
\hline & $N / n$ & $\%$ & $N / n$ & $\%$ & $p^{* *}$ \\
\hline Ruptured amniotic sac & $85 / 171$ & $50 \%$ & $58 / 241$ & $24 \%$ & $<0.001$ \\
\hline Use of oxytocin & $75 / 171$ & $44 \%$ & $122 / 241$ & $51 \%$ & 0.19 \\
\hline Previous vaginal birth & $82 / 171$ & $48 \%$ & $71 / 241$ & $29 \%$ & $<0.001$ \\
\hline Successful vaginal birth & $144 / 171$ & $84 \%$ & $141 / 241$ & $59 \%$ & $<0.001$ \\
\hline
\end{tabular}

Abbreviation: SD, standard deviation.

Notes: ${ }^{*} p$ value obtained using the unpaired Student $t$-test; ${ }^{* *} p$ value obtained using the Fisher exact test.

We found a higher incidence of cases of induced labor with misoprostol among pregnant women between 20 and 30 years of age, which is similar to the data found in the literature. ${ }^{14}$ Maternal age can influence the unsuccessful labor induction due to: the less robust vasculature and an insufficient hemodynamic demand during pregnancy; ${ }^{15}$ the gradual decrease in myometrial contraction function; ${ }^{16}$ and the higher incidence of medical comorbidities in advanced maternal age. ${ }^{17}$ Regardless of parity, advanced maternal age ( $\geq 35$ years) is independently associated with an increased risk of cesarean section following labor induction (adjusted odds ratio [OR]: 2.29; 95\% confidence interval [95\%CI]: $1.64-3.20 ; p<0.001){ }^{18}$

Table 3 Stepwise regression analysis to predict the success of labor induction with misoprostol according to previous vaginal delivery

\begin{tabular}{|c|c|c|c|c|c|}
\hline & \multicolumn{2}{|c|}{$\begin{array}{l}\text { Previous vaginal birth } \\
(n=153)\end{array}$} & \multicolumn{2}{|c|}{$\begin{array}{l}\text { No previous vaginal } \\
\text { birth } \\
(n=259)\end{array}$} & \multirow[b]{2}{*}{$p^{*}$} \\
\hline & Mean & SD & Mean & SD & \\
\hline Age (years) & 28.4 & 5.8 & 22.3 & 5.1 & $<0.001$ \\
\hline Number of previous births & 3.1 & 1.3 & 1.1 & 0.4 & $<0.001$ \\
\hline Parity & 1.9 & 1.2 & 0.0 & 0.0 & $<0.001$ \\
\hline Number of previous miscarriages & 0.2 & 0.5 & 0.1 & 0.4 & 0.13 \\
\hline Bishop score & 3.6 & 1.0 & 3.2 & 1.0 & $<0.001$ \\
\hline Number of misoprostol tablets & 2.6 & 1.9 & 2.7 & 1.9 & 0.39 \\
\hline \multirow[t]{2}{*}{ Time of induction (hours) } & 17.3 & 11.8 & 19.5 & 11.6 & 0.07 \\
\hline & $N / n$ & $\%$ & $N / n$ & $\%$ & $p^{* *}$ \\
\hline Ruptured amniotic sac & $42 / 153$ & $27 \%$ & $101 / 259$ & $39 \%$ & 0.02 \\
\hline Use of oxytocin & $72 / 153$ & $47 \%$ & $125 / 259$ & $48 \%$ & 0.84 \\
\hline Bishop score $>6$ & $82 / 153$ & $54 \%$ & $89 / 259$ & $34 \%$ & $<0.001$ \\
\hline Successful vaginal birth & $130 / 153$ & $85 \%$ & $155 / 259$ & $60 \%$ & $<0.001$ \\
\hline
\end{tabular}

Abbreviation: SD, standard deviation.

Notes: ${ }^{*} p$ value obtained using the unpaired Student $t$-test; ${ }^{* *} p$ value obtained using the Fisher exact test. 
Successful labor induction with misoprostol occurred in the majority of the pregnant women (59.2\%) with a low dose of this drug $(25 \mu \mathrm{g}$ to $50 \mu \mathrm{g})$. This result is consistent with the findings reported by Tsikouras et al, $^{19}$ which confirmed the safety and efficacy of $50 \mu \mathrm{g}$ of misoprostol in inducing labor in low-risk and postterm pregnant women ( $>40$ weeks), as well as in women with an unfavorable cervix (Bishop score $\leq 6)$. A lower dose of misoprostol is also associated with a lower incidence of adverse effects on the mother and fetus, such as tachysystole, uterine hyperstimulation and fetal metabolic acidosis. ${ }^{20}$

According to some protocols, PGE1 is administered to promote cervical ripening as the first step in the labor induction of pregnant women with unfavorable uterine cervices. Prostaglandin E1 alone initiates labor, and oxytocin is obviously needed for the conduction of labor. ${ }^{21}$ In our study, 197 pregnant women (47.8\%) required oxytocin after induction with misoprostol to continue labor.

Brusati et $\mathrm{al}^{22}$ evaluated the efficacy of $25 \mu \mathrm{g}$ of sublingual misoprostol in inducing labor in single births. They found that vaginal birth occurred within 24 hours in $78 \%$ of multiparous women and in $65 \%$ of nulliparous women. In our study, not only parity, but also the Bishop score, the amount of misoprostol administered, the time of induction, the use of oxytocin, and prior vaginal births were all associated with the successful induction of labor.

Many studies have shown that, when compared with expectant management, induced labor in cases of full-term pregnancy is associated with a reduction in perinatal mortality. ${ }^{23-25}$ The traditional method for predicting whether labor will be induced successfully in cases of vaginal birth is the presence of a favorable cervix, as determined by the Bishop score. In the past, some studies demonstrated that the Bishop score rarely predicted the success of induced labor. ${ }^{26-28}$ Recently, a review of the Cochrane Library, which included 234 patients, compared the Bishop score to the assessment of cervix length by transvaginal ultrasound to determine the success of induced labor. ${ }^{29}$ According to this review, there is no clear superiority of one method over another to assess the pre-induction of the cervix for the following post-natal outcomes: vaginal birth (OR: 1.07; 95\% CI: 0.92-1.25); cesarean section (OR: 0.81 ; 95\%CI: $0.49-$ 1.34); and admission to a neonatal intensive care unit (OR: 1.67; 95\%CI: 0.41-6.71). Our study used a stepwise regression analysis to identify the pre-induction factors that could be used as predictors of a successfully induced labor. We found that a Bishop score between 4 and 5 and previous vaginal birth were independent factors with statistical significance in the prediction of a successful vaginal birth.

The most common indication for cesarean section was unsuccessful induction (10.9\%). According to a study by Pajak et $\mathrm{al}^{30}, 12 \%$ of post term pregnant women had unsuccessful labor induction with misoprostol $50 \mu \mathrm{g}$ every 12 hours (maximum: $150 \mu \mathrm{g}$ ). A total of $18 \%$ of the pregnant women required 8 to 11 hours between the start of labor and delivery. Sharami et al $^{31}$ obtained an average of 13.2 hours in a group of 633 primigravidae who received a $50-\mu \mathrm{g}$ vaginal dose of misoprostol. Santo et $\mathrm{al}^{32}$ used $25 \mu \mathrm{g}$ of misoprostol placed in the posterior vaginal fornix and found an average time between induction and the start of the active phase of labor of 10 hours and 20 minutes, while labor lasted for an average of 15 hours and 35 minutes.

One limitation of our study is the fact that it is a retrospective study. In addition, we did not evaluate the influence of body mass index on the success of induced labor. However, this study included 412 patients who were duly monitored until the end of labor, which enabled the proper assessment of the maternal outcomes.

\section{Conclusion}

The present study concluded that successful labor induction with misoprostol occurred in the majority of the pregnant women with a low dose of this drug. Higher Bishop scores and previous vaginal deliveries were the best predictors of vaginal delivery when $25 \mu \mathrm{g}$ of misoprostol was administrated vaginally.

\section{References}

1 Moraes Filho OB, Cecatti JG, Feitosa FEL. [Methods for labor induction.]. Rev Bras Ginecol Obstet 2005;27(08):493-500Portuguese.

2 Sanchez-Ramos L. Induction of labor. Obstet Gynecol Clin North Am 2005;32(02):181-200, viii

3 ACOG Committee on Practice Bulletins - Obstetrics. ACOG Practice Bulletin No. 107: induction of labor. Obstet Gynecol 2009;114 (2 Pt 1):386-397

4 Mackenzie IZ. Induction of labour at the start of the new millennium. Reproduction 2006;131(06):989-998

5 Tang OS, Schweer H, Seyberth HW, Lee SW, Ho PC. Pharmacokinetics of different routes of administration of misoprostol. Hum Reprod 2002;17(02):332-336

6 Stephenson ML, Wing DA. Misoprostol for induction of labor. Semin Perinatol 2015;39(06):459-462

7 Boulvain M, Kelly A, Irion O. Intracervical prostaglandins for induction of labour. Cochrane Database Syst Rev 2008;(01): CD006971

8 Souza ASR, Scavuzzi A, Rodrigues DC, Oliveira RD, Feitosa FE, Amorim MM. [Titrated oral solution of misoprostol for labour induction: a pilot study]. Rev Bras Ginecol Obstet 2010;32(05): 208-213Portuguese.

9 Kavanagh J, Kelly AJ, Thomas J. Hyaluronidase for cervical ripening and induction of labour. Cochrane Database Syst Rev 2006;(02): CD003097

10 Rezaie M, Farhadifar F, Sadegh SM, Nayebi M. Comparison of vaginal and oral doses of misoprostol for labour induction in postterm pregnancies. J Clin Diagn Res 2016;10(03):QC08-QC11

11 Duro Gómez J, Garrido Oyarzún MF, Rodríguez Marín AB, de la Torre González AJ, Arjona Berral JE, Castelo-Branco C. Vaginal misoprostol and cervical ripening balloon for induction of labor in late-term pregnancies. J Obstet Gynaecol Res 2017;43(01):87-91

12 Hofmeyr GJ, Gulmezoglu AM. Vaginal misoprostol for cervical ripening and induction of labour. Cochrane Database Syst Rev 2001;(03):CD000941

13 Blanchard K, Clark S, Winikoff B, Gaines G, Kabani G, Shannon C. Misoprostol for women's health: a review. Obstet Gynecol 2002; 99(02):316-332

14 Oliveira TA, Melo EM, Aquino MM, Mariani Neto C. [Efficacy of dinoprostone and misoprostol for labor induction in nulliparous women]. Rev Bras Ginecol Obstet 2011;33(03):118-122 Portuguese. 
15 Naeye RL. Maternal age, obstetric complications, and the outcome of pregnancy. Obstet Gynecol 1983;61(02):210-216

16 Main DM, Main EK, Moore DH II. The relationship between maternal age and uterine dysfunction: a continuous effect throughout reproductive life. Am J Obstet Gynecol 2000;182 (06):1312-1320

17 Arrowsmith S, Robinson H, Noble K, Wray S. What do we know about what happens to myometrial function as women age? J Muscle Res Cell Motil 2012;33(3-4):209-217

18 Dunn L, Kumar S, Beckmann M. Maternal age is a risk factor for caesarean section following induction of labour. Aust N Z J Obstet Gynaecol 2017; [ Epub ahead of print ]

19 Tsikouras P, Koukouli Z, Manav B, et al. Induction of labor in postterm nulliparous and parous women - potential advantages of misoprostol over dinoprostone. Geburtshilfe Frauenheilkd 2016; 76(07):785-792

20 Blickstein I. Induction of labour. J Matern Fetal Neonatal Med 2009;22(Suppl 2):31-37

21 Wing DA [Internet]. Induction of labor with oxytocin. 2017 [cited 2017 May 21]. Available from: <https://www.uptodate.com/contents/induction-of-labor-with-oxytocin $>$

22 Brusati V, Brembilla G, Cirillo F, et al. Efficacy of sublingual misoprostol for induction of labor at term and post term according to parity and membrane integrity: a prospective observational study. J Matern Fetal Neonatal Med 2017;30(05):508-513

23 Stock SJ, Ferguson E, Duffy A, Ford I, Chalmers J, Norman JE. Outcomes of elective induction of labour compared with expectant management: population based study. BMJ 2012;344:e2838
24 Darney BG, Snowden JM, Cheng YW, et al. Elective induction of labor at term compared with expectant management: maternal and neonatal outcomes. Obstet Gynecol 2013;122(04): 761-769

25 Boulvain M, Senat MV, Perrotin F, et al; Groupe de Recherche en Obstétrique et Gynécologie (GROG). Induction of labour versus expectant management for large-for-date fetuses: a randomised controlled trial. Lancet 2015;385(9987):2600-2605

26 Friedman EA, Niswander KR, Bayonet-Rivera NP, Sachtleben MR. Relation of prelabor evaluation to inducibility and the course of labor. Obstet Gynecol 1966;28(04):495-501

27 Hughey MJ, McElin TW, Bird CC. An evaluation of preinduction scoring systems. Obstet Gynecol 1976;48(06):635-641

28 Dhall K, Mittal SC, Kumar A. Evaluation of preinduction scoring systems. Aust N Z J Obstet Gynaecol 1987;27(04):309-311

29 Ezebialu IU, Eke AC, Eleje GU, Nwachukwu CE. Methods for assessing pre-induction cervical ripening. Cochrane Database Syst Rev 2015;(06):CD010762

30 Pajak J, Tomiałowicz M, Florjański J, et al. [Comparison of vaginal misoprostol and oxytocin for labor induction in post-term pregnancy]. Ginekol Pol 2001;72(12A):1300-1304Polish.

31 Sharami SH, Milani F, Faraji R, et al. Comparison of $25 \mu \mathrm{g}$ sublingual and $50 \mu \mathrm{g}$ intravaginal misoprostol for cervical ripening and labor: a randomized controlled equivalence trial. Arch Iran Med 2014;17(10):652-656

32 Santo S, Lourenço R, Centeno M, et al. Labor induction with 25microg misoprostol vaginal capsules. Gynecol Obstet Invest 2009; 68(04):272-275 